\title{
WILLIAM THOMAS GREEN MORTON
}

\section{(1819-68)}

\author{
By \\ W. R. BETT, M.R.C.S., L.R.C.P., F.R.S.L. \\ "to keep men out of their Urnes, and \\ discourse of humane fragments in them"
}

The tale of William Thomas Green Morton is as incredible as it is obscure, and as pathetic as it is sordid. The records of his historic achievement which has made his name echo down the corridors of time are scarcely less confused and bewildering than are the almost legendary stories of his childhood. Born on August 9, I8I9, at Charlton, a village in Worcester County, Massachusetts, son of a prosperous farmer and shopkeeper, Morton was a highly-strung, neurotic boy, who, consumed by the ambition to become a doctor, allegedly spent his time dosing his playmates with pills concocted of bread and leaves and on one occasion nearly killed his baby sister, asleep in her cradle, by forcing some "weird compound" down her throat. At the age of thirteen, he was sent to the Academy of Oxford where he boarded with the local doctor. In his second year, however, he ran away from school, having been unfairly punished. Feeling homesick, he also ran away from his next school. At Northfield Academy he is said to have occupied his leisure hours searching the countryside for minerals rather than playing with the other boys. When he was about to embark on the study of medicine, his father lost his money, so that he had to go into business instead. His first job with a Boston publishing house proving distasteful, he returned home a few months later to work in his father's shop. Quickly tiring of this, he set up business on his own, which soon failed. We next read of him in 1840 studying dentistry at the Baltimore College of Dental Surgery, the first dental school established in America and probably in the world (now the University of Maryland School of Dentistry), but his name does not appear on the list of graduates. It is more probable that he received his dental training from Horace Wells of Hartford, Connecticut, Nathan C. Keep, and possibly also from Horace Hayden, one of the founders of the College. During the winter of I842 to I843 Wells and Morton practised together at I9, Tremont Street, Boston. About this time Wells advertised in the papers a superior method of putting in false teeth, which, however, necessitated removal of old roots left in the jaw by in- competent dentists-by far too painful a process for any patient to countenance. In disappointment the impatient Wells resigned from the partnership in the autumn of $\mathrm{I} 843$, returning to Hartford, while Morton remained in Boston, both realising that a fortune could be made out of painless dentistry. Morton now fell in love with a sixteen year old school girl at Farmington, Connecticut, Elizabeth Whitman, who considered him very handsome and very much in love with her, as: he came regularly from Boston to visit her. It was his promise to give up dentistry and take up medicine that finally won Morton her parents". consent. The tale is told that the impossible bridegroom took a skeleton on the honeymoon, his thoughts busy nearly all the time with the study of anatomy. Morton matriculated at Harvard University Medical School, where he attended the lectures, but he was not graduated with his class of 1846 , the medical course at that time only occupying two years. All his spare moments were devoted to dental practice, his mechanical ingenuity bringing him in much work as a plastic surgeon. $\mathrm{He}$ also established a profitable factory for the manufacture of porcelain teeth ("tooth mill"). During 1844 he lived with that amazing psychopathic character Chärles Thomas Jackson, physician and chemist, to whom he was apprenticed and from him he learnt that ether applied to the outside of a painful tooth renders it less sensitive and also that riotous medical students inhaled ether for their amusement. Jackson, too, had demonstrated before his chemical classes that inhalation of ether causes unconsciousness. In July of that year, at his teacher's suggestion, Morton employed ether in drops as a local anaesthetic during the filling of a tooth. In the spring of 1846 it appears that he asked Jackson for a gas rubber bag, receiving instead a flask with a tube inserted in it and some ether, of the properties of which, curiously enough, he pretended to be ignorant. After inhaling the ether himself and becoming unconscious for seven or eight minutes, he also tried its effects on an apprentice and, if we are to believe the fanciful and exceedingly dubious reports, in the summer of 
I846 on a goldfish, a hen, green worms, and his pet water spaniel named Nig, who, on recovering consciousness, performed the incredible stunt of jumping ten feet into a pond. Morton's wife complained that his clothes seemed constantly to be saturated with the smell of ether, and she did not like it. His first patient was the musician Eben Frost, from whom on September 30, I846, he extracted an upper bicuspid tooth painlessly under ether anaesthesia. The scared patient had asked to be mesmerised, but the dentist assured him that he knew a better trick than mesmerism. The story of Morton's greatest triumph, when at ten o'clock on the morning of October I6, I846 ("Ether Day"), in the amphitheatre of the Massachusetts General Hospital, Boston, he publicly administered ether to a young printer, Gilbert Abbott by name, and succeeded in convincing the world that this was "no humbug," is told elsewhere in this issue. That he refused to disclose the nature of his anaesthetic agent whose colour, odour, and taste he skilfully disguised, will always be remembered against him. To ensure the secrecy of his "letheon," Morton jointly with Jackson applied for letters patent, which were issued on November I2th for a period of I4 years. When in I849 Morton petitioned Congress for a financial reward, he was immediately opposed by Jackson and by the relatives of the late Horace Wells. The notorious and vulgar ether controversy had started. Morton, trying vainly to make a fortune out of his discovery, devoted the last twenty years of his life to hopeless litigations, writing pamphlets, preparing speeches, and issuing appeals to medical societies. Though he was given financial support from several sources, he spent much more than he received, being reduced to dire poverty. During the Civil War he claimed to have administered ether to wounded soldiers after several battles. There are no official records that he enlisted in the Union army. It was probably as a civilian that in May, I864, he visited the scene of the Battle of the Wilderness, where he remained some ten days.
The extraordinary anecdote has survived of how气 he presented himself at Grant's headquarters? successfully using his reputation as the discovere of anaesthesia to borrow an ambulance to go "sight $\leftarrow$ seeing." He died on July I5, I868, at the age of 48 , of apoplexy. Tradition insists that this was? precipitated by reading a publication recently issued on behalf of Jackson to prejudice a testimonial subscription being raised for himself $\vec{\Phi}$ Leaping from his buggy in New York's Centrab Park, he ran to a lake to cool his burning brain ands fell unconscious on the ground. Moribund he wastaken to St. Luke's .Hospital, where he died anhour or two later. The chief surgeon, turning tow a group of house pupils, is said to have exclaimed: "Gentlemen, you see lying before you a man whoo has done more for humanity and the relief. of. suffering than any man who has ever lived." N

Among the Morton memorials may be mentionedin a bust in the United States National Museum $N$ Smithsonian Institution, Washington, and a replica in the New York University Hall of Fame; a bust in the Ether Dome of the Massachusetts Generab Hospital, Boston; and a bronze tablet on the house of his birth in Charlton.

Slightly above medium height, with dark: piercing eyes, bushy brows, side-whiskers, and 2 a黑 military aggressive moustache, quick of thouggt $\vec{\bullet}$ and movement, Morton appears on the shabley stage of the grand ether drama as the man of action; the go-getter, the showman. Hard-headed ando ruthless, his manners were agreeable, and, even in the heat of controversy, he is described as havingo been forbearing. Though handicapped by lack of culture and scientific training, in many ways he had been exceptionally lucky. That in someo of his claims and speeches he was essentially un- $\frac{3}{5}$ truthful is perhaps as pathological a trait of the man as is his persecution phobia which began in early life. His only son William James Morton M.D., became a pioneer in the use of X-rays in the United States. 